\title{
Cultural Background on Reading Comprehension in Junior High School
}

\author{
Xiaoling Yang \\ Foreign Language School, Nanchang Normal University, Nanchang, Jiangxi, China
}

\begin{abstract}
Reading ability is the important part of English learning and the close relationship between language and culture determines the significant impact of cultural background knowledge on reading comprehension. The cultivation of students' English cultural awareness and sensitivity of English culture should be paid attention at the beginning. In this paper, the impact of the cultural knowledge on reading comprehension here is emphasized. And how to improve the junior high school students' cultural background is also discussed further.
\end{abstract}

Index Terms — cultural background, reading comprehension, ways, improve

\section{INTRODUCTION}

English as a tool of communication has been playing a more significant part in the modern society; it is the main channel to obtain information in foreign language. Many countries especially China has regarded it as the second language or first foreign language to learn to adapt to the society's developing. As Juri Lotman ever said: "no language can exist unless it is stepped in the context of culture; and no culture can exist which does not have, at its corner, the structure of natural language."(Lotman, 1978, pp23-211) Language and culture are interdependent. It is language that distinguishes humankind from other animals. The belief that there is a very close relationship between language and culture has long been held by anthropologists.

In recent years, with the deepening and popularizing of the research of the intercultural communication, more and more foreign language teachers have formed such a consensus, foreign language teaching is not only for cultivating students' ability of listening, speaking, reading and writing, but also helping students possess another competence---cultural competence. At the same time, cultural competence will retroact to students' English learning especially the English reading competence which is the most important part of English learning. Nevertheless, the current situation of reading teaching in junior high school is not optimistic since many students are still lack of necessary background knowledge or awareness of cultural difference. It is necessary for teachers intentionally to help improve students' cultural background knowledge. The culture teaching which aims to improve students' reading competence should follow some principles and measures. And this will be discussed in this paper.

\section{The CuRrent Situation of ReAding Comprehension In Junior High SchoOL}

Reading is a highly complicated human behavior. It is a thinking process that sets two people in interactivity together---an author and a reader. It is by no means an easy job to give a definition. Many researchers prefer not providing a definition of reading as simple definitions usually misrepresent complex cognitive processes of reading. In Grabe's view, "a description of reading has to account for the notions that fluent reading is rapid, purposeful, interactive, comprehending, flexible, and gradually developing." (Grabe, 1997, pp198) He suggests that description of basic knowledge and processes required for fluent reading is a more appropriate starting point.

English reading ability is the important part of English learning. English reading has been playing a more significant part in acquiring cultural, economic, scientific and technical knowledge, for collecting worldwide information and carrying out international exchange and cooperation. Hence, the importance of English reading is self-evident; it is the most important measure to absorb English language materials. Alderson and Urquhart believe that it has significant influence on one's academic research, professional success and personal development.

Moreover, though reading is an issue at all grade levels; it is increasingly significant in middle school. In the field of basic education, the significance of reading in English is overtly recognized in China. The New English Curriculum Standard regulates that the middle school English teaching should lay particular emphasis on the cultivation of reading competence. This is reflected in the paper of Senior High School Entrance Exam of English in China with full mark of 150. 50 marks are directly for reading comprehension and other 40 marks are associated with reading ability. Reading skills are essential to the academic achievement of middle and high school students.

At last, reading has proved to be an efficient way to cultivate a good language sense and accumulate language experience. To Chinese who take English as a foreign language rather than the second language, listening, speaking, reading, and writing are four basic skills in English study. Of the four skills, reading means the most, it is the basic and prerequisite of the other three language skills---listening, speaking, and writing as well as the main method for students 
to expand their vocabulary, and it is just like a natural green house where students can grow vocabulary in their mind as much as they like to.

As the importance of reading has been in focus for so long, enough attention has been paid to how to improve the English reading comprehension. However, though many experts have devoted into the English reading teaching research, the result is not satisfied.

The current situation of reading teaching in junior high school is not optimistic since it is universal to see that after three years' education of junior high school; however, many students in senior middle school of China still lack sufficient proficiency as readers. They are unable to read effectively, and frequently fail to comprehend texts. As a matter of fact, our traditional English reading teaching has long been affected by the Grammar-Translation Approach (GT approach), which is inspired by the teaching of Greek in 19th century. GT approach views that, as the basic unit of language, written sentence consisting of a series of describable rules. Only when students know these rules and master enough vocabulary can they translate quickly and accurately from foreign language to mother tongue. It considers mother tongue as the basis of learning a foreign language, and students should translate the text properly into their mother tongue so that they can comprehend the text. Actually, for a variety of reasons, in most junior high schools of China, this traditional way of teaching still prevails.

In real EFL classrooms of junior school, teachers pay more attention to the translation of the text, emphasizing the new words, important phrases and grammar in an attempt to help students improve reading comprehension. They think that if students could acquire the meaning of each word, each sentence, and each paragraph, they will have no difficulties in comprehending the whole text in this way. However, the fact is on the contrary. In many cases, the majority of the junior students misunderstand or feel puzzled over the meaning of the text, even though they understand every single word and all the grammatical structures. They cannot get the general idea or give proper response after reading a text. Sometimes they are slow in interpreting texts with relatively more new words or complicated sentence structures in them because they have to consult the dictionary from time to time.

And during the English reading teaching class, everything is arranged well by the teachers, including what students to learn, how to learn, even what to learn for. Teachers make full use of every minute in class to "teach" their students so as to ensure that students can understand. Accordingly, the students are busy taking notes when listening to their teacher attentively. However, they are only mechanical note-takers. Because they are put into a very passive position in this way, they only bring their ears to class, and they have no chance to express their ideas, let alone discuss with the teacher or with other students. Therefore, the teaching process is prolonged and some students may feel boring and tired of reading comprehension gradually. What is more, the effect is not apparent, some students even do not understand the general idea of the text after being taught in light of paying too much attention to the individual language points instead of the over-all meaning of the information that passage carries.

\section{RElationships BETWEEN CULTURAL BACKGROUND AND READING COMPREHENSION}

As we have discussed above, the role of background knowledge in language comprehension has been formalized as schema theory. According to schema theory, comprehending a text is an interactive process between the reader's background knowledge and the text. Text cannot be understood correctly without cultural background knowledge. Many experts claim that there are two factors affecting reading comprehension; the first one is the degree and speed of brain's perception of word symbols, it means the readers' linguistic knowledge in other words; the other one is the effect of "something behind the eyes". The so-called "something behind the eyes" refers to the readers' cultural background knowledge. Therefore, necessarily cultural background knowledge is very important to reading. As far as background knowledge is concerned, Carrel said: "In the EFL/ESL classroom, we must be particularly sensitive to reading problems that result from the implicit cultural background knowledge presupposed by a text." (Carrel, 1983)The term "cultural background knowledge" is also sometimes referred to as all the information and ideas, all the perceptions and concepts, as well as the intellectual residues of emotional expressions, held in long-term memory by readers. Paulston and Bruder also point out that learning to read is easier "when the cultural background is familiar and students can draw on cultural information in the decoding process", in their book, Teaching English as a Second Language: Techniques and Procedures (Paulston,1976, pp5-6).

Heilman et al. In 1986 proposed that "background knowledge can be thought of as an individual's experiential/conceptual background for (1) written text (word recognition capabilities, concept of print, understanding word order, and understanding word meanings) as well as for (2) the content of what he is reading" Reading comprehension is a function of cultural knowledge. (Heilman, 1999, PP 25-32).

In every text that we are teaching, many words and sentences are culture-loaded. In other words, they found that cultural knowledge plays a vital role in reading comprehension. Efficient comprehension requires the ability to relate the textual material to one's own cultural background knowledge.

China has lagged behind in the culture teaching of foreign languages compared with the Western countries. In the past half century, there has been a strong commitment to include culture in the language curriculum. During the next two decades, people were entirely prohibited from learning anything from foreign culture due to be motivated by the intention of protecting the home culture and maintaining its tradition. With the opening up of China, international contact increased rapidly, English, as a tool of communication, has been paid more attention to. Meanwhile, many 
books and articles concerning language and culture came out. Nowadays the importance of culture teaching has been widely recognized in teaching English as a foreign language, and the cultivation of cultural awareness has been prescribed clearly in the new English Curriculum Standard as one of the five basic goals in English teaching, which takes the new Junior English for China as its source material, the new English Curriculum Standards as its foundation and junior high school students as its specific objects. However, although most of the EFL teachers have already recognized the importance of cultural background knowledge, the study of these issues remains superficial and rarely achieves any substantial progress, especially in junior high school. Actually, the English teachers in junior school usually neglect culture teaching intentionally or unintentionally or sometimes select some of aspects of culture in English teaching due to time limitation. In addition, many students see little or no connection between language learning and culture learning. According to the current situation, the author has concluded three current problems existing in the English culture teaching in China.

\section{A. The Limit of the English Tests}

Liu Runqin pointed anxiously in his article English Teaching in 21 Century that the present English teaching is more from a business purpose instead of developing culture and social. (Liu, 1988)This is what sensible people worried. Today, most of the English teachers still cannot get away of the bondage of the exam baton though they have realized the important significance of cultural knowledge in the English language learning process. At present, all kinds of test blots out the sky, and most of the exam content is to check students' mastering of the English language knowledge. Whether students' learning includes cultural content doesn't have much influence on their final scores in the test. In this guidance of examination, the cultural content is rare involved in the exercises and exam papers students usually do, teachers inevitably pay much more attention to the teaching of language knowledge, and neglect the cultural content contained in language during the teaching process.

\section{B. The Environment and the Pressure}

Affected by Chinese deeply rooted traditional culture, students feel difficult to accept in thought and emotion when facing the new Western culture. It is hard for students to cultivate the cross-cultural awareness due to lack of authentic environment for cross-cultural communication even in the English classes. Occasionally, when there have chances for them to communicate with the foreign friends face by face, the cultural mistakes they make when disturbed by cultural differences will be understood by the foreign friends consider the restriction of students' age and language knowledge.

What's more, English is just one of the many subjects the junior students have to learn every day. To distribute the study time of each course reasonably determines students not to spend much time to study the cultural content contained in language, or acquaint themselves with some simple polite expressions and cultural customs in the situational dialogues related to the test at most. More of their time and energy are put into memorizing new words and phrases, reciting the text and doing exercises.

\section{The Restriction of the Teachers' Qualities}

Fostering talents with cultural consciousness need teachers with high language quality and literary attainments. At present, almost all the English teachers in China are native Chinese whose mother tongue is not English, and their living environment and background are nearly the same with students', so there are not big cultural differences between teachers and students. The cultural knowledge they possessed is acquired indirectly from books, and doesn't have the vitality. So in cultural teaching, part of the language teachers take the attitude of withdrawal as they think the content is too deep, complex and not easy to operate. Even though in the teaching of cultural knowledge, they just echo what books say, rigid and boring. Consequently, the improvement of English teachers' quality and accomplishment is the primary task of smoothly cultural teaching.

However, although there are many theories about culture teaching in foreign language education and the importance of teaching culture in foreign language education has been realized, it is rarely discussed how to integrate culture teaching and foreign language instruction in junior high school and how to apply theories to real classroom activities. Thus how to improve students' cultural background knowledge becomes an urgent and foremost requirement for English teachers.

\section{WAYs to Improve CUltural BACKGROUND IN JUNIOR High SCHOOL}

As the importance of cultural background knowledge has been recognized in the past few decades, great efforts have been made in order to promote the English cultural teaching and some good results have been achieved. But just as we have seen, the present English culture teaching, still being incomprehensive, imperfect and unsystematic, has not integrated language teaching well with culture teaching. Here are some suggestions for foreign culture teaching.

\section{A. The Principles of Culture Teaching}

The foreign culture teaching should be carried out in accordance with these three principles: The Assimilative Principle, The Phasic Principle and The Comparative Principle.

The Assimilative Principle is to transform and assimilate the parts of target culture which are identified benefit to native culture, and let the useful parts become parts of native culture gradually. Essentially, the absorption is to live 
better and develop better, in order to enrich local culture, and make it distinctive to the world culture. The Phasic Principle in fact is the principle which request the introduction of cultural content should be step by step. To determine the cultural content according to students' language level, receiving and comprehending ability, go from the shallower to the deeper, from simple to complex and from phenomena to essence. And the Comparative Principle is an attempt to make a comparison between the students' own culture and target culture so as to find out their similarities and differences. It is necessary for the teachers intentionally to make the students aware of the diversities between two cultures through such methods as differentiating, contrasting or comparing so as to make the alien culture part of the students. To make comparison is perhaps one activity that may help Chinese EFL students to understand foreign culture as well as their home culture.

\section{B. Role-playing}

Role-playing or dramatization is a very useful way for junior students to learn the English language culture, as students can be engaged in the topic and their understandings and cultural background knowledge can be activated. Students may get access to real life experiences in the role-play activities, especially activities concerning cultural differences. For example, students can do a role-playing where they act out the scenes which respectively happened in the shops in China and the Western countries. When shopping in shops of China, the salesman or saleswoman usually would ask "what do you want?" to the customers, while this sentence is very impolite to Western people. Actually in the Western countries they are used to say "Can I help you?" or "What can I do for you?" Besides, students can also do the role-playing activities offered in the English books, and discuss if the situations are common in the western countries. There is a conversation in Lesson 17 in JEFC Book 3.

A: Hello, you look tired today.

B: Yes, 1 went to bed too late last night...

A: You'd better go to bed earlier tonight if you can.

This suggestion is actually more widespread in China. However, in token of concern in English-speaking countries, A should say "I'm sorry to hear that" "Take good care of yourself" or "I do hope you'll be feeling better soon". Through this way, students' cultural awareness and knowledge would be strengthened and improved as it offers students the opportunity to be involved in cross-cultural learning and response upon cultural differences.

\section{After-class Reading}

Reading is the main method to gain information. As the cultural background knowledge is extremely limited in junior students' text books, reading after-class is an effective way to help students to improve their cultural knowledge. On one hand, students should learn cultural knowledge actively after class, they should not learn the cultural knowledge selectively according to the test content or just neglect it in order to have more time to prepare for the exam in which the cultural knowledge is not required; on the other hand, students should expand their knowledge horizons. They can get well known with the art, history, customs and habits directly through reading the English original works such as the English literary works, newspapers, magazines and watching movies from the English spoken countries. For example, students can get familiar with the western table manners through reading "Table Manners". Through the after-class reading, they will know that the Herculean task is a very difficult task which Hercules is the Roman name for the Greek mythological hero Heracles, and the Watergate scandal is one of the most inglorious political scandals in American history. In addition, students can make full use of the Internet to acquire more aspects of the foreign cultural information and understand the cultural differences which cannot be learned in class.

\section{Talking with the English Native Speakers}

Talking with the English native speakers is the best and direct way for students to get well known with the cultural differences as a nation's culture background is reflected through its people's manners and ways of thinking. With the fast development of the economy of the world, there are many chances for communicating with foreigners/English native speakers. Students should talk with the English speakers as more as possible. They can learn much knowledge that cannot be found in the text books and reference books which is the English speakers' personal experience. It can help junior students to check whether the foreign language knowledge they learned consistent with the foreign cultural background knowledge.

Take the greeting way for example, when people meet in the Western countries, they would say "hello" or "how are you? " or "good morning/afternoon/evening?" and the subject they usually talk is about the weather. However in China, people generally ask "have you had your lunch? (你吃了吗?) "as the greeting way. In addition, talking with the English speakers will not only promote the students' comprehending the foreign cultural knowledge but also help them to overcome the effect of cultural differences and know well with the cultural knowledge entirely and exactly. For instance: the Chinese greeting "have you had your lunch?" may arouse the misunderstanding of the Western people. Since in China, it is just regarded as a common greeting which is no more than a western way of saying hello or hi, nevertheless, to the Westerners, it could indicate an invitation to a meal, it might means "I haven't either, let's go together and get something to eat." or "if you haven't, I am just going to invite you to my place." Thus, when a student asks the foreign this question to show friendliness during their communication, he may be misunderstood but simultaneously corrected by the foreign. 
Therefore, through talking with the English native speakers, students' knowledge about the English speaking countries' social life, customs, greeting ways and the modes of thinking would be promoted immediately.

\section{CONCLUSION}

Reading is a comprehending process which combines the known information with the unknown information. Possessing the related culture background knowledge will contribute to the students' accurate understanding of the texts as more known information can promote comprehension. According to Schema theory, comprehending a text is an interactive process between the reader's background knowledge and the text. Text can't be understood correctly without cultural background knowledge. Therefore, in English teaching, teachers should try to make students understand the language in its cultural context. Students can never be expected to learn English well without learning and understanding the culture of the native English speakers. In the EFL classroom in junior high school, teachers should attach great importance to cultural factors in the language learning process and integrate cultural knowledge and information into the teaching curricula.

Besides, the culture teaching and learning should be carried out according to the three principles mentioned in the article. Teachers should not only improve personal qualities to teach the cultural background knowledge more accurately, comprehensively and widely, but also help improve students' cultural awareness and lead the students to attach importance to cultural language learning. Meanwhile, students should also lay emphasis on the cultivation of their cultural background knowledge on their initiatives. They can accumulate and rich their background knowledge through the English text-supplementary materials (e.g. workbooks, and reading passages in the collection of practice tests) as well as the other readings (e.g. English novels, stories, newspapers and journals), try to make full use of the Internet and make themselves more contact with the foreign cultural knowledge. In conclusion, students' reading comprehension competence will have great improvement if they are well known of the cultural background knowledge (Lia, 2001).

\section{REFERENCES}

[1] Carrel, P. L., \& Joan C. Eisterhold. (1983). Schema theory and ESL reading pedagogy. TESOL Quarterly, 17, 473-533.

[2] Lia, D. S. (2001). Cultural barrier of chinese student's English reading. Teaching of Foreign Language, 4, 72-77.

[3] Heilman, (1999). Culture in second language teaching and learning. Shanghai: Shanghai Foreign Language Education Press, 25-32.

[4] Lotman, J. \& Uspensky, B. A. (1978). On the semiotic Mechanism of Culture, New York History, IX (2), 32-211.

[5] Paulston and Bruder. (1976). Communication between Cultures. Beijing: Foreign Language Teaching and Researching Press, $5-6$.

[6] Grabe, S. D. (1977). Introduction to linguistics--2nd Ed. New York, McGraw-Hill, 198.

[7] Liu R. Q. (1988). Culture and reading comprehension. English Teaching in 21 century, 3, 72-75.

Xiaoling Yang was born in Nanchang, China in 1970. She received master degree in linguistics from East China Technology University, China in 2005.

She is currently professor in the School of Foreign Language, Nanchang Normal University, Nanchang, China. Her research interests include English Teaching and Cross-culture.

Prof. Yang is a member of Jiangxi Association of English. 